DOI: $10.31866 / 2410-1915.21 .2020 .207866$

UDC 111.852:167:7.03'06

\title{
AESTHETICS OF MODERNITY AT THE TURN OF THE CENTURY: MODERN - POSTMODERN - HYPERMODERN - METAMODERN
}

\author{
Nadiia Babii
}

$\mathrm{PhD}$ in Art Studies, Associate Professor, ORCID:0000-0002-9572-791X, nbabij26@gmail.com, Vasyl Stefanyk Precarpathian National University, 57, Shevchenka St., Ivano-Frankivsk, 76000, Ukraine

\section{For citations:}

Babii, N. (2020). Aesthetics of Modernity at the Turn of the Century: Modern - Postmodern Hypermodern - Metamodern. Culture and Arts in the Modern World, 21, 23-33. https://doi. org/10.31866/2410-1915.21.2020.207866.

The purpose of the article is to analyse the interpretations and transformational processes of the definition of "aesthetics of modernity" in the culturological thought at the end of the $20^{\text {th }}-$ early $21^{\text {st }}$ centuries. To this end, the study applies methods of critical analysis, contextualism, as well as a methodology relevant to the systematic culturological approach, including the method of synthesis and the system method. The scientific novelty of the work lies in the fact that the transformation of the aesthetic images of modernity in the applied culturological science has been analysed. Conclusions. It has been demonstrated that new postulates of aesthetic values are formed in the cultural and artistic environment and only later are comprehended and institutionalized by the rest of the society. The main characteristic of the "modernity" of the turn of the century is its accelerated variability. The study demonstrates the transformation of aesthetic values, which occurs between the creation of original modifications, the social purpose of art (modern), quoting, general pluralism, asociality, chaotic or transitivity (postmodern), the loss of corporeality, the total acceleration, consumption culture (hypermodern), ultimately returning to normal practices, but in the conditions of hyper-accelerated time. Metamodern is considered as the boldest attempt to comprehend modernity, using the concept of "structure of feeling" as a state of being here and now before its comprehension. It should be noted that the number of non-traditional approaches to the system of knowledge, practising the use of chaos theory is growing. It is proved that the understanding of the artistic direction precedes the definition of the time period, used as a colourful definition of modernity, which has not yet become a historical epoch. In each of the periods, understanding of novelty has no total characteristics, and is determined by diffusion, invasiveness, combining simultaneously the features of old and new, but each time in a new capacity. Before being legalized in scientific theories, each of the variants of modernity was structured primarily in artistic practices and, having reached an agreement with the general public opinion, lost its relevance in the sense of aesthetic newness. Each time we use a new prefix, we agree with the statement that society, along with the idea of modernity, has changed.

Keywords: aesthetics of modernity; transformational processes; modern; postmodern; hypermodern; metamodern. 


\section{Introduction}

The interpretation of the "modernity" in the light of aesthetics is important for understanding of various aspects of human being, including the definition of cultural and art processes and practices.

The actual contents and context of modernity in each historical era requires more complex and more combined definitions which sometimes integrate quite opposite factors. And the differences in interpretation depend on geographical, political and cultural features of individual scientific schools. There is uncertainty in the way of writing and use of terminology, which indicates the fluidity of cultural periods and their heterogeneity, the introduction of special terms in every day practices.

Therefore, the scientific discourse related to the interpretation and transformation of the aesthetic through the perspective of the understanding of the modernity (the end of the $20^{\text {th }}$ - the first quarter of the $21^{\text {st }}$ centuries) becomes relevant. The identified issues have also led to the choice of sources and personalities associated with time frames and cultural definitions.

A large number of foreign and domestic theoretical works, which deals with postmodernity and are characterized by a variety of methodological approaches, are related to the national schools (centre or periphery), cultural traditions (Europe, the USA, post-Soviet states), areas of expression in the fields of art, exact sciences or humanities.

The issue of the separation of the aesthetic in the sense of modernity is primarily related to the name of Charles Baudelaire. In the $20^{\text {th }}$ century the theory of postmodernism was institutionalized mainly in the works of French and American philosophers: Jean-Francois Lyotard (1995), Jacques Derrida (2001), Jean Baudrillard (2002); later Reinhart Koselleck (2005), Wolfgang Welsh (2004). Arthur Kroker and David Cook (1986), John Armitage (1999), Paul Virilio (2002), Gilles Lipovetsky (2015) consider the transformation of modern, hypermodern, metamodern.

As to domestic researchers, the issue of postmodernism and a number of aesthetic views of that time was expressed for the first time by the Ukrainian writer and editor-in-chief of "Pleroma" magazine, Volodymyr Yeshkiliev (1998), some of the author's recent writings have focus on hypermodern issues. He claims that "a person simultaneously remains a creation, invention and instrument of the culture created by him" and states that "authority cannot (and will not be able to) control a person in all its manifestations", the example of which is "online democracies" of hypermodern or "proxy democracy" of authoritarian regimes that rely on electorate affected by NLP technologies". Today, people with smart phones want to create political performances and design new identities (Yeshkiliev, 2020).

The monograph by Orest Losyk contains reviews and translation of Western European critical literature, emphases the importance of artistic practices in the formation of postmodernism and defines a postmodern interpretation of freedom which is interpreted as an active civil, public and private position of a person (Losyk, 2016, p. 302). 
The works of Aleksander Zbrzezny are devoted to the issues of understanding of "modernity" (Zbrzezny, 2014). Aleksandr Pavlov notes that neither a term (sociology of hypermodernism) nor its meaningful content is popular with other philosophers and culturologists, which makes hypermodernism at best a weak alternative to postmodernism (Pavlov, 2019, p. 29).

Despite the large amount of research, it should be noted that most authors focus their attention on criticism, therefore, the theoretical question of understanding of the development of the aesthetics of modernity requires specification, comprehension and arrangement.

\section{Purpose of the article}

To analyse the interpretations and transformational processes of the definition of "aesthetics of modernity" in the culturological thought at the end of the $20^{\text {th }}$ - early $21^{\text {st }}$ centuries.

The study applies methods of critical analysis, contextualism, as well as a methodology relevant to the systematic culturological approach, including the method of synthesis and the systemic method. The scientific sources are analysed with the help of these methods, the existing theories as to the understanding of the aesthetics of modernity, its images and transformation processes are collected and validated. Based on the analysis of the world scientific discourse, the transformation of the aesthetic images of modernity in the applied culturological science is analysed.

\section{Main research material}

The intention to conceptualize the modernity is associated with a natural desire to arrange, rationalize, and search for the foundations of their own existence. In philosophical and cultural science, "modernity" is interpreted as a qualitatively new stage, different from the previous one. In this dissociation from the "past", the understanding of the aesthetics of "modernity" is somewhat conditional since art and creativity, in a broad sense, always relies on previous experience and tradition. It is important to understand that in different countries, the generational boundaries, as well as the division into periods of stylistic trends, are significantly shifted.

German scientist in the field of historiosophy Reinhart Koselleck (2005) explores the conceptual field of "modernity", considering it in synchrony and desynchrony areas, so, by his definition, each story was, is and will be the history of modernity (p. 259). The scientist considers the values of progress: emancipation, acceleration, and democracy as the key factors that distinguish the "newest". The new, in his opinion, is not necessarily new in essence, but only in form (Koselleck, 2005, p. 251). G. H. Lewes identified the level of a "new", connecting it with the level of results and the level of emergents when "components of the "new" are not present in the "old" in sufficient fullness of its attributes" (Yeshkiliev, 1998).

According to Charles Baudelaire, modernité does not mean a historical time (epoch), but the understanding of the nature of Beauty. Those who "delve into 
the past, lose the memory of the present, renounce the values and privileges of the actual moment are mistaken, because nearly all our originality comes from the print that time leaves on our impressions" (Losyk, 2016, p. 29). However, while emphasizing the lightening of the moment, of momentary time, of actuality, Baudelaire also insists on the primacy of eternity as the distinct direction of the actual.

Anna Sydor (2014), looking for domestic interpretation of Baudelaire's understanding of modernity, compares the dictionary interpretation of French modernité with the synonym "modernism" (p.103); however, she notes that the Ukrainian and French understanding of the concept of "modernism" is narrower and is used to denote a specific style direction of the late $19^{\text {th }}-$ early $20^{\text {th }}$ centuries, while "...modernité rather means the modern era, reality, modern life". This term is derived from the late Latin modernus, in the sense of "actual", which, in turn, originated from the Latin word modo ("just, recently")...".

It should be noted that the French word contemporanéité, which is also a noun that means the quality, condition, character of what is considered to be modern, is the analogue to the French word modernité (CNRTL, n.d). The same dictionary lists synonyms for "modern" - simultanéité, synchronie, which mean - "simultaneous", "synchronous", presént - "present". The etymology of the French adjective contemporain comes from the Latin word contemporaneous, cum tempus, the English word contemporary - means "modern", but has several interpretations:

- belonging to the same period of time, contemporary;

- of about the same age, occurring at the present time, current.

In this article we are considering many variants of spelling of the terms that occur in the Ukrainian language: modern, modernity, modernism, postmodern, postmodernism; with a capital letter; separately - post modernism, with a hyphen - post-modernism. Analysing the way of their use in texts, it is difficult to notice the difference in the definition. Postmodern and postmodernism, hypermodern, hypermodernism are often used simultaneously as synonyms in the same text (Pavlov, 2019, p. 21), although, when "modern" denotes the historical period, we write it with a capital letter, whereas, art style - with a small letter, a cultural and intellectual direction - with the suffix "-ism" (Gutculiak, 2016). We use the original author's spelling of terms in quotations in a definite study. In our own definitions, we avoid the capital letter, which assigns to modernity the understanding of chronologically passed and institutionalized; historical time.

Polish dictionaries provide several variants of words to describe modernity (nowoczesność, wspólczesność, ponowoczesność, post-ponowoczesność), but among all synonyms, the most common is nowoczesność, which means 'an ideological and spiritual attitude aimed at updating the lost, traditional selfconsciousness" (Losyk, 2016, p. 19). Aleksander Zbrzezny (2014) denies nowoczesność as a historical epoch, but treats it as a special form, or rather a way of functioning of culture and society (p. 237).

Volodymyr Yeshkiliev defines the new according to three hierarchical levels:

- just new (results); 
- qualitatively new (emergents);

- completely new. And notes with scepticism that “... in contemporary art (the 90 's of the $20^{\text {th }}$ century - Author's notes) the fundamentally new... is possible only under the circumstances that themselves are qualitatively new in the beyond-art spheres of life (a change of "aion" according to C. G. Jung, apocalyptic transformations of existing)...” (Yeshkiliev, 1998).

The aesthetic understanding of modernity as postmodernity is associated with many sometimes radically distinctive features. The first cases of the term usage do not have a common determinant of qualitative characteristics, they relate to a separate use, or the individual arts, or the issues of aesthetics, politics; they are not characterized by a stable link to the general chronology. The beginning of dating of the "postmodern" discourse is connected with the prism of ideas that were extended in circles of North American literary criticism in the 1950s and 1960s, wherefrom they were spread to art criticism and, at the same time, art in the 1970s (Losyk, 2016, p. 58). It was only in the next decade that these ideas were formed in the world-view sciences - philosophy, aesthetics, sociology, political science, anthropology, history, theology, etc. In Eastern European countries, the debate about the legitimization of postmodernism as a cultural phenomenon for objective reasons began in the late 1990s and continues actively to this day. The number of supporters of postmodern modernity, as well as its antagonists, is huge, certified by thousands of bibliographies, as well as the widespread use of the term in everyday practice. Nonconformists and the Underground culture are trying to attract creativity to the postmodern.

At first, the discussion around postmodernism was defined as "the sad fall of the wave after the majestic crest of modernity" (Welsch, 2004, p. 28), but soon postmodernism became associated with democracy and pluralism, which bridges the gap between high art and mass culture, critics and the public, professionals and amateurs. Postmodern declares new opportunities, the new in the growth of diversity. To understand the transformation processes of the aesthetic representation of the new, it should be noted that "...postmodern discourse is not based on the assertion of the emergent originality of its modifications and agrees with the "situation of quoting", that is, making simply "new" (Yeshkiliev, 1998).

Postmodern art practice is implemented in two ways: hermetic conceptualism declares deconstruction, the philosophy of emptiness, notes the vulnerability of the world; mass culture and pop art, on the other hand, promote a comfortable stay in society, which displaces the elite and the mass, provides everyone with equal access to art and other benefits. Postmodern irony accompanies both directions simultaneously, amusing culture is used to overcome fear, and self-irony is used as an attempt to rehabilitate one's own culture and its achievements.

At the end of the second decade of the $21^{\text {st }}$ century, the use of the term "postmodernism" is unacceptable in the context of defining the aesthetic foundations of modernity, because it has required an attribute of a specific chronology. Describing the era of total digitalization, presence and terrorism, the most common are new temporal categories that denote an alternative to postmodern - the generalized term post-postmodern (Hutcheon, 2002). The fragmentary 
definitions are employed in the contexts: performatism, automodern, digitimodern, altermodern, renovalism, and more global: hypermodern, transmodern, metamodern.

The concept of Western European society as hypermodern was proposed by Gilles Lipovetsky (Lipovetsky, 2015), but, as in the case of postmodernism, the use of the term and variations in understanding has appeared long before (Kroker \& Cook, 1986, p. 8). In the understanding of Kroker and Cook, postmodernism is not the beginning of something new or the end of something old. This is a catastrophe that will become possible because of the entertainment, the implosion of modern culture. Their category of panic is accompanied by degradation in all spheres of culture and politics (Kroker \& Cook, 1986, p. 247). Describing modernity, the authors pay much attention to the human body, predicting its transformation in the direction of complete rejection of the body (Kroker \& Cook, 1986, pp. 20-34). Ivan Varga simultaneously discusses the relationship of all "-isms". In his opinion, just as modernity did not distance itself from pre-modernity, postmodern had a lot in common with modern hypermodern is organically connected with postmodern, even strengthening the characteristics of the latter. In public presentations of the body, there is a return of pre-modern practices: the use of decoration in the form of tattoos, piercing, and so on. However, these practices do not bear signs of sociality, on the contrary, they distinguish an individual from the society, and are the sign of its instability (Varga, 2005, pp. 211-212). In Varga's opinion, hypermodern society uses technology to operate with possibilities outside the human body that were not previously available, virtuality excludes corporeality, and the body becomes a simulacrum.

Exploring the media, John Armitage (Armitage, 1999) refers to the works of Paul Virilio, who, describing the culture of modernity, the role of the United State's policy in it, noted that the latest war was speed, acceleration. Acceleration of communications leads to compaction of real time. The space factor is changed by the time, and the material is replaced by the immaterial. Relevant for today "There is no longer "here", but there is "now" (Virilio, 2002, pp. 92-93). Armitage predicts an ecological catastrophe that would give birth to a new culture, and in Virilio's works the prefix "hyper-" is identical to "super-", so the society is still in modernity (Armitage, 1999, p. 26). Hypermodern is associated not only with the body, but with the definition of culture.

In the "Aestheticization of the world", the theory of hypermodernity acquires a positive meaning through the formulation of "transesthetics", which is considered in the context of commercial and popular art (Pavlov, 2019, p. 28). Reflections on hypermodern are formed around the issues about the phenomenon of hyper consumption, but Lipovetsky sees a positive thing in the unlimited consumerism in the fact that it ultimately leads to the need for cultural creation.

Describing the problem of resistance to hypermodern technologies, Volodymyr Yeshkiliev (2020) notes that “...democracy often takes the majority's side on issues where the majority has never been, is not and will not be right (for example, in the sphere of cultural tastes or creative experiments)". 
In the general scientific discourse on the status of modernity, perhaps the most discussed concept is metamodern, which starts with a specific aesthetic definition, originated in transmodernism, and has been formulated into a fullfledged socio-cultural paradigm, where the term oscillation means fluctuations between enthusiasm and irony. Timotheus Vermeulen and Robin van den Akker criticize all previous attempts to formulate "- isms", and formulate "Structure of feeling" as metamodern. The prefix "meta-" simultaneously reflects the understanding of "together", "between" and "beyond": epistemologically, metamodernism is "together with" (post)modernism, ontologically "between" (post) modernism and historically "beyond" (post)modernism. Sensuality is controlled by the subjects themselves, which consciously agree to self-deception (Vermeulen \& Akker, 2010, p. 4).

The theory of metamodern from the sphere of art and culture gradually seeps into the sphere of scientific research. In the essay "Metamodern View of Science", Hanzi Freinacht (2018) reflects on the absurdity of the traditional methods of knowledge, since modernity tends to expect the unexpected. The metamodern theory is actively discussed not only in Europe and America, but also in the post-Soviet space, including Ukraine, where the Ukrainian translation of the "Manifesto" was presented in 2016. The characteristics of the new modernity include: logic of binanizm, naivety, fundamental incompleteness, the cessation of the search for aesthetic and plastic absolute in favour of the study of the variable boundaries of art and the limits of knowledge. The absence or unacceptability of known cultural and philosophical methods for understanding of the new modernity is proposed to supplement with new ones at the intersection of art and science, not only in the sense of exact sciences (art \& science), but also in the humanities (art \& studies), quoting: "We should embrace the scientific-poetic synthesis and informed naivety of a magical realism. Error breeds sense" (Turner \& Labaff, 2016). The modern researcher is also an artist, whose scientific work is personal creative experience at each moment of time, and the main task is to construct atmospheres as the creation of conditions for living a certain sensory experience in spite of language constructions that are currently imperfect in terms of understanding modernity.

\section{Conclusions}

Thus, new postulates of aesthetic values are formed in the cultural and artistic environment and only later are comprehended and institutionalized by the rest of the society. The main characteristic of the "modernity" of the turn of the century is its accelerated variability. Therefore, the transformation of aesthetic values occurs between the creation of original modifications, the social purpose of art (modern), quoting, general pluralism, asociality, chaotic or transitivity (postmodern), the loss of corporeality, the total acceleration, consumption culture (hypermodern), ultimately returning to normal practices, but in the conditions of hyper-accelerated time. Metamodern is the boldest attempt to comprehend modernity, using the concept of "structure of feeling" as a state of being here and now before its comprehension. It should be noted that the 
number of non-traditional approaches to the system of knowledge, practicing the use of chaos theory is growing.

It is proved that the understanding of the artistic direction precedes the definition of the time period, used as a colourful definition of modernity, which has not yet become a historical epoch. In each of the periods, understanding of novelty has no total characteristics, and is determined by diffusion, invasiveness, combining simultaneously the features of old and new, but each time in a new capacity. Before being legalized in scientific theories, each of the variants of modernity was structured primarily in artistic practices and, having reached an agreement with the general public opinion, lost its relevance in the sense of aesthetic newness. Each time we use a new prefix, we agree with the statement that society, along with the idea of modernity, has changed.

\section{References}

Armitage, J. (1999). From Modernism to Hypermodernism and Beyond: An Interview with Paul Virilio. Theory, Culture \& Society. http://www.kyoolee.net/From Modernism_to_Hypermodernism_and_Beyond___Interview_with_Paul_Virilio.pdf [in English].

Baudrillard, J. (2002).V tini movchaznoi bilshosti, chy Kinets sotsialnoho [In the shadow of the silent majority, or the End of the social]. "I"", 25, 77-88 [in Ukrainian].

Centre National de Ressoures Textuelles et Lexicales (CNRTL). (n.d.). Contemporanéité. [Contemporaneity]. In CNRTL.fr/etymologie. Retrieved March 17, 2020, from https:// www.cnrtl.fr/etymologie/contemporan\%C3\%A9it\%C3\%A9 [in French].

Derrida, J. (2001). Struktura, znak i hra v dyskursi humanitarnykh nauk [Structure, sign and game in the discourse of the humanities]. In M. Zubrytska (Ed.), Antolohiia svitovoi literaturno-krytychnoi dumky XX st. [Anthology of world literary-critical thought of the twentieth century] (pp. 617-640). Litopys [in Ukrainian].

Dictionary.com. (n.d.). Contemporary. In Dictionary.com. Retrieved March 17, 2020, from https://www.dictionary.com/browse/contemporary [in English]

Freinacht, H. (2018, December 4). Metamodernizm: pohliad na nauku [Metamodern View of Science]. Velyka ideia. https://biggggidea.com/practices/metamodernizmpoglyad-na-nauku/ [in Ukrainian].

Gutculiak, O. (2016). Modern, modernizm, Postmodern i postmodernizm [Modern, Modernism, Postmodern and Postmodernism]. Proza.ru. https://www.proza. $\mathrm{ru} / 2$ 016/03/17/170?fbclid=IwAR2J 72NmMikJKP9hheDIYV1tGvG7Q7ogSwRAHOYZLXK1fRWyWsRe2KuQcc [in Russian].

Hutcheon, L. (2002). The Politics of Postmodernism. Routledge [in English].

Koselleck, R. (2005). Mynule maibutnie. Pro semantyku istorychnoho chasu [The past is the future. On the semantics of historical time]. Dukh i litera [in Ukrainian].

Kroker, A., \& Cook, D. (1986). The Postmodern Scene. Excremental Culture and HyperAesthetics. New World Perspectives [in English].

LaRousse. (n.d.). Modern. In LaRousse: Dictionnaire de Francais. Retrieved March 17, 2020, from https://www.larousse.fr/dictionnaires/francais/moderne/51945 [in French].

Lipovetsky, G. (2015). Time Against Time, or The Hypermodern Society. Supplanting the Postmodern. In D. Rudrum, \& N. Stavris (Eds.), Anthology of Writings on the 
Arts and Culture of the Early $21^{\text {st }}$ Century (pp. 191-208). Bloomsbury Academic [in English].

Losyk, O. (2016). Fenomen svobody i frantsuzkyi postmodernism [The phenomenon of freedom and French postmodernism]. Doslidno-vydavnychyi tsentr Naukovoho tovarystva imeni Shevchenka [in Ukrainian].

Lyotard, J.-F. (1995). Sytuatsiia Postmodernu [Postmodern situation]. Filosofska $i$ sotsiolohichna dumka, 5-6, 15-38 [in Ukrainian].

Pavlov, A. (2019). Obrazy sovremennosti v XXI veke: gipermodernizm [Images of modernity in the $21^{\text {st }}$ Century: Hypermodernism]. Filosofskii zhurnal, 12(2), 20-33 [in Russian].

Sydor, A. (2014). "Khudozhnyk suchasnoho zhyttia". Estetychno-ideina kontseptsiia suchasnosti Sh. Bodlera ["Artist of modern life". The aesthetic and ideological concept of modernity of S. Baudelaire]. Foreign Philology, 126(2), 103-110 [in Russian].

Turner, L. \& Labaff, S. (2016). Manifest Metamodernizmu [The Metamodernist Manifesto]. The Syncretic Times. https://thesyncretictimes.wordpress.com/2016/02/22/ metamodernist-manifesto-ukrainian/ [in Ukrainian].

Varga, I. (2005). The Body - The New Sacred? The Body in Hypermodernity. Current Sociology, 53(2), 209-235. https://doi.org/10.1177/0011392105049538 [in English].

Vermeulen, T. \& Akker, R. van den. (2010). Notes on Metamodernism. Journal of Aesthetics \& Culture, 2, 1-14. https://doi.org/10.3402/jac.v2i0.5677 [in English].

Virilio, P. (2002). Informatcionnaia bomba. Strategiia obmana [Informational bomb. Cheating strategy] (I. Okunev, Trans.). Gnozis [in Russian].

Welsch, W. (2004). Nash postmodernyi modern [Our postmodern modernism] (A. Bohachova, M. Kultaieva, \& L. Sytnichenko, Trans.). Alterpres [in Ukrainian].

Yeshkiliev, V.(1998). Nove v literaturi [New in literature]. Plieroma, 3. http://www.ji.lviv. ua/ji-library/pleroma/gk-mo.htm [in Ukrainian].

Yeshkiliev, V. (2020). Pechat vichnoho sprotyvu i transformatsiia demokratii [Seal of eternal resistance and transformation of democracy]. Matrix Divergent. https:// matrix-info.com/pechat-vichnogo-sprotyvu-i-transformatsiya-demokratiyi [in Ukrainian].

Zbrzezny, A. (2014). Milczenie syren [Mermaids silence]. Przegląd Filozoficzny - Nowa Seria R. 23, 1(89), 229-241. https://doi.org/10.2478/pfns-2414-0019 [in Polish]. 


\section{ЕСТЕТИКА СУЧАСНОСТІ НА ЗЛАМІ ТИСЯЧОЛІТЬ: МОДЕРН - ПОСТМОДЕРН - ГІПЕРМОДЕРН - МЕТАМОДЕРН}

\section{Бабій Надія Петрівна}

Кандидат мистецтвознавства, доцент, ORCID:0000-0002-9572-791X, nbabij26@gmail.com, Прикарпатський національний університет імені Василя Стефаника, Івано-Франківськ, Україна

Метою статті $є$ аналіз інтерпретації та трансформаційні процеси визначення «естетики сучасності» у культурологічній думці наприкінці XX - початку XXI століття. Для досягнення мети були використані методи критичного аналізу, контекстуалізму, а також методологія, відповідна системному культурологічному підходові, в тому числі метод синтезу та системний метод. Наукова новизна полягає в тому, що прослідковано трансформацію естетичних образів сучасності в прикладній культурологічній науці. Висновки. З'ясовано, що нові постулати естетичних цінностей формуються у культурномистецькому середовищі і лише згодом осмислюються, інституалізуються рештою соціуму. Основна характеристика «сучасності» зламу тисячоліть - її прискорена змінність. Визначено трансформацію естетичних цінностей, яка відбувається поміж творенням оригінальних модифікацій, соціальним призначенням мистецтва (модерн), цитуванням, загальним плюралізмом, асоціальністю, хаотичністю чи перехідністю (постмодерн), втратою тілесності, тотальним прискоренням, споживацькою культурою (гіпермодерн), зрештою поверненням до звичаєвих практик, однак в умовах гіперприскореного часу. Метамодерн уявляємо найсміливішою спробою осмислити сучасність, використовуючи концепцію «структури відчуттів» як стану перебування тут і зараз до його осмислення. Відзначимо зростання кількості нетрадиційних підходів до системи пізнання, що практикують використання теорії хаосу.

Доведено, що розуміння мистецького напряму передує визначенню часового періоду, вживається як колоритне означення сучасності, що ще не стала історичною добою. У кожен із періодів розуміння новизни не має тотальної характеристики, а відзначається дифузністю, інвазійністю, поєднуючи одночасно риси старого та новітнього, однак щоразу у новішій якості. Перш ніж узаконитись у наукових теоріях, кожен із варіантів модерну структуризувався найперше у мистецьких практиках i, дійшовши до порозуміння із загальною суспільною думкою, втрачав актуальність у сенсі естетичного нового. Щоразу використовуючи новий префікс, ми тим самим погоджуємось на твердження, що суспільство, а разом із ним і уявлення про сучасність змінились.

Ключові слова: естетика сучасності; трансформаційні процеси; модерн; постмодерн; гіпермодерн; метамодерн. 


\title{
ЭСТЕТИКА СОВРЕМЕННОСТИ НА СТЫКЕ ТЫСЯЧЕЛЕТИЙ: МОДЕРН - ПОСТМОДЕРН - ГИПЕРМОДЕРН - МЕТАМОДЕРН
}

\author{
Бабий Надежда Петровна \\ Кандидат искусствоведения, доцент, \\ ORCID: 0000-0002-9572-791X,nbabij26@gmail.com, \\ Прикарпатский национальный университет имени Василия Стефаника, \\ Ивано-Франковск, Украина
}

Целью статьи является анализ интерпретации и трансформационные процессы определения «эстетики современности» в культурологической мысли в конце XX - начале XXI века. Для достижения цели были использованы методы критического анализа, контекстуализма,атакжеметодология,соответствующаясистемномукультурологическому подходу, в том числе метод синтеза и системный метод. Научная новизна заключается в том, что прослежена трансформация эстетических образов современности в прикладной культурологической науке.

Выводы. Выяснено, что новые постулаты эстетических ценностей формируются в культурно-художественной среде и только потом осмысливаются, институализируются остальным социумом. Основная характеристика «современности» перелома тысячелетий - ее ускоренная изменчивость. Определена трансформация эстетических ценностей, которая происходит между созданием оригинальных модификаций, социальным назначением искусства (модерн), цитированием, общим плюрализмом, асоциальностью, хаотичностью или переходностью (постмодерн), потерей телесности, полным ускорением, потребительской культурой (гипермодерн), в конце концов возвращением к традиционным практикам, однако в условиях гиперускоренного времени. Метамодерн представляем смелой попыткой осмыслить современность, используя концепцию «структуры ощущений» как состояния пребывания здесь и сейчас к его осмыслению. Отметим рост числа нетрадиционных подходов к системе познания, практикующим использование теории хаоса. Доказано, что понимание художественного направления предшествует определению временного периода, используется как колоритное определение современности, которая еще не стала исторической эпохой. В каждый из периодов понимание новизны не имеет полной характеристики, а отмечается диффузностью, инвазивностью, объединяя одновременно черты старого и нового, однако каждый раз в более новом качестве. Прежде чем узакониться в научных теориях, каждый из вариантов модерна структурировался сначала в художественных практиках и, дойдя до понимания с общим общественным мнением, терял актуальность в смысле эстетического нового. Каждый раз используя новый префикс, мы тем самым соглашаемся на утверждение, что общество, а вместе с ним и представление о современности изменились.

Ключевые слова: эстетика современности; трансформационные процессы; модерн; постмодерн; гипермодерн; метамодерн. 